\title{
Research on the Influencing Factors of Dollar Exchange Rate Fluctuation after Financial Crisis
}

\author{
Ruoxi Gong \\ Majoring in Statistics and Minoring Economics, Boston University, MA02215, America
}

Keywords: Dollar index, Fluctuation, Purchase Power Parity, Influencing factors

\begin{abstract}
The dollar plays a central role in the international monetary system, and the fluctuations of the dollar exchange rate affect the nerves of the global economy. Therefore, based on the analysis of the dollar index fluctuation after the financial crisis, combined with the PPP exchange rate decision theory and balance of payments and international trade theory, this paper adopts the method of qualitative analysis to study the influencing factors on the dollar exchange rate after the financial crisis. Research shows that: United States GDP is a key factor affecting the dollar exchange rate. In addition, the rate of inflation, fiscal balance, the current account balance, the international price of gold is important factors of dollar exchange rate.
\end{abstract}

\section{Introduction}

Since the Bretton Woods system was established, it has experienced the collapse of the Bretton Woods system and the establishment of the Jamaica system, but the dollar has always been the central currency in the international monetary system. The United States has strong economic strength, the dollar is the main currency of valuation and settlement in international trade, the world's major commodities, such as oil, energy, gold and so on, are denominated in us dollars. At the same time, the international capital market is mainly denominated in US dollars. The US dollar is the largest trading volume in the international exchange market, and the US dollar is also the reserve foreign exchange of the central banks of the world. At present there are more than 50 countries around the world will direct its currency pegged to the dollar, even in a few countries such as Panama, Ecuador, Zimbabwe and other countries have been as legal currency in domestic circulation, sovereign currency treatment. Therefore, the US dollar is an internationally recognized "anchor currency", which is the vane of the international financial market.

With the deepening of globalization, exchange rate occupies an increasingly important position in the open economy, and various macro and micro variables interact with each other through various channels, affecting the economic nerve of each country. After the disintegration of the Bretton Woods system, the floating exchange rate system was widely adopted by the major Western economies. Under the floating exchange rate, the market determines the exchange rate level, which helps to improve the efficiency of resource allocation, so that the price of money reflects its true value. However, the floating exchange rate system also makes the exchange rate fluctuate frequently, which aggravates the risk of foreign exchange. The dollar is the center of the international monetary system, so it is particularly necessary to study the factors affecting the dollar exchange rate. In this paper, through the analysis of the global financial crisis in 2008 after the US dollar exchange rate changes, combined with the traditional exchange rate theory and exchange rate theory of international payments pointed out the impact factors of the dollar, the dollar exchange rate for the study and judgment and grasp the pre-global economic context to provide a certain reference.

\section{Fluctuation Analysis of Dollar Exchange Rate}

In 1985, the New York cotton exchange set up a financial sector, formally entered the global financial markets, the first launch is the dollar index futures. Dollar index futures, based on the trade settlement between the major countries and the United States, calculates the overall strength of the 
dollar by weighted average. The dollar index is a comprehensive reflection of the dollar exchange rate in the international foreign exchange market index used to measure the dollar's exchange rate against a basket of currencies, reflecting the degree of the dollar, so the dollar index instead of the dollar.

The dollar index (Fig. 1)showed a cyclical rise from 2008 to early 2015 and reached its peak in April 7, 2015, and then declined. Specifically, the dollar index changed from a continuous decline before the crisis to a cyclical fluctuation that first increased and then decreased, and there were multiple peaks. The first peak was in the full eruption of the financial crisis in August 2008, and the market panic soared. When everyone thought the dollar index continued to fall, the dollar was unexpectedly strong, and the dollar index soared. In 2010 June, the first European debt crisis broke out, which seriously hit the revival process of European economy. In 2011, the yen rose against the dollar by the earthquake and nuclear power accidents. To help Japan tide over the crisis, G7 announced the joint sale of yen and buying dollars. In 2012, the second European debt crisis broke out, with the first European debt crisis spread, the dollar index ushered in a new round of higher. Since then, the U.S. Federal Reserve launched the impact of QE3 and QE4, the U.S. dollar index has experienced concussion. But with the improvement of the economic fundamentals in the United States, and the Federal Reserve gradually withdraw from the QE, the dollar index rose again in 2014, climbing to 95.47 points in March 2, 2015, and then volatility declined.

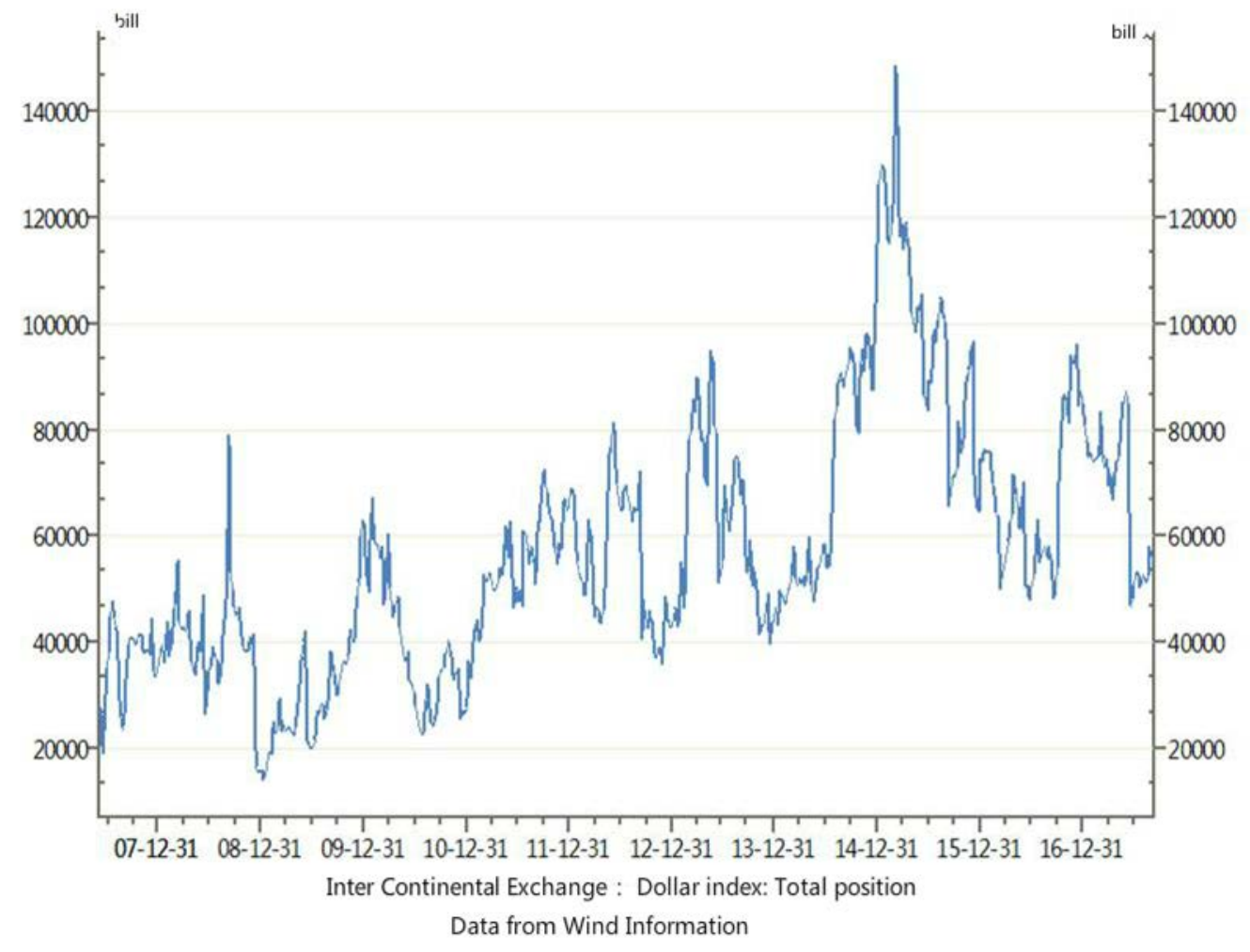

Fig. 1Trend of dollar index

\section{Reasons Analysis of Dollar Exchange Rate Fluctuation Based on Traditional Exchange Rate Determination Theory}

Traditional Exchange Rate Determination Theory. The PPP (Purchasing Power Parity) theory is the basis of all the exchange rate decision theory. The value of the theory that money is its purchasing power, comparison between different currencies exchange depends on their purchasing power, namely the exchange rate and the price level are directly related. There are two forms of purchasing power parity theory: absolute purchasing power parity and relative purchasing power parity. Absolute purchasing power parity refers to the equilibrium exchange rate between domestic currency and foreign currency equal to the ratio of purchasing power or price level between China and foreign currencies. Absolute purchasing power parity that a country's currency value and the 
demand for it is a unit of currency in China can buy goods and services is determined by the amount, decided to buy it from the two countries, so the currency exchange rate between the two countries can be expressed as the ratio of the purchasing power of money. The purchasing power is reflected by the price level. According to this equation, the rise in domestic prices would mean the devaluation of the national currency relative to foreign currencies. Relative purchasing power parity makes up for some deficiencies of absolute purchasing power parity. Relative Purchasing Power Parity refers to the relative change of the purchasing power of money in different countries, and it is the decisive factor of exchange rate change. The main factor of exchange rate fluctuation is the relative change of purchasing power or price between different countries; compared with the period when the exchange rate is in equilibrium, the ratio of purchasing power between the two countries has changed. The exchange rate between the two currencies must be adjusted. Although the theory has encountered many difficulties in practical applications, its proposition is of great significance. The purchasing power parity theory from the basic function of money to explain the problem of currency exchange, and first explain the monetary problem from the quantity of money point of view, its two forms: absolute purchasing power parity and relative purchasing power parity is also very concise.

Reasons Analysis of Dollar Exchange Rate Fluctuation. According to the above analysis chart of the dollar index, combined with the PPP, the impact factors including the dollar exchange rate: U.S. gross national product (GDP), the consumer price index (CPI), the fiscal deficit, the current account balance, the price of gold, the international oil price.

GDP. When the economic environment is good, when the economic growth, the United States can provide more competitive international investment returns, thereby increasing the international money market demand for the dollar, and the dollar index increased. After the financial crisis in 2008, the dollar index fluctuated upward, which was directly related to the economic recovery of the United States after the crisis. As shown in Table 1, the United States in 2014 and 2015 GDP growth rate of $2.4 \%$, although it did not reach the United States in the average level in 1980s and 90s, but have been very close to the average growth rate since 2000, especially compared with the crisis after a few years, this data is indeed impressive. In the international horizontal comparison, the United States economic growth is also stronger than most economies. In 2015, in the developed countries, Japan's GDP growth rate is only $0.4 \%$, while Germany is only $1.5 \%$; in developing countries, South Africa's GDP growth of $1.3 \%$, Russia and Brazil are respectively 3.7\% and 3.8\% decline. That is to say, as long as China is stronger than China, the economic growth of the United States is strong and the recovery is obvious. Under the background of the good basic national economy in the United States, the dollar index page shows an upward trend.

In addition, the economic growth rate is the key factor affecting the U.S. dollar exchange rate. This is because the rate of economic growth not only directly affects the dollar exchange rate, but also indirectly affects the U.S. dollar exchange rate through a variety of other ways. First, the economic growth speed will increase the possibility of the Fed rate hike; second, economic growth and prosperity will increase people's income, improve the real estate prices, foreign demand for goods and services increased, thereby increasing the current-account deficit; third, economic growth in the tax rate unchanged will expand the tax base and increase revenue and reduce the fiscal deficit, high exchange rate of US dollar; fourth, the good momentum of economic development, the Fed will gradually withdraw from the quantitative easing monetary policy, reducing the volume of currency, the dollar exchange rate increase; fifth, after the financial crisis, Japan's economic downturn, Europe suffered two times the debt crisis, the economic recovery in the road blocked the major developed countries, the U. S. economy is the only economic trends for the better, and natural capital while avoiding disadvantages, so the international capital A lot of money goes to the United States, raising the dollar exchange rate. 


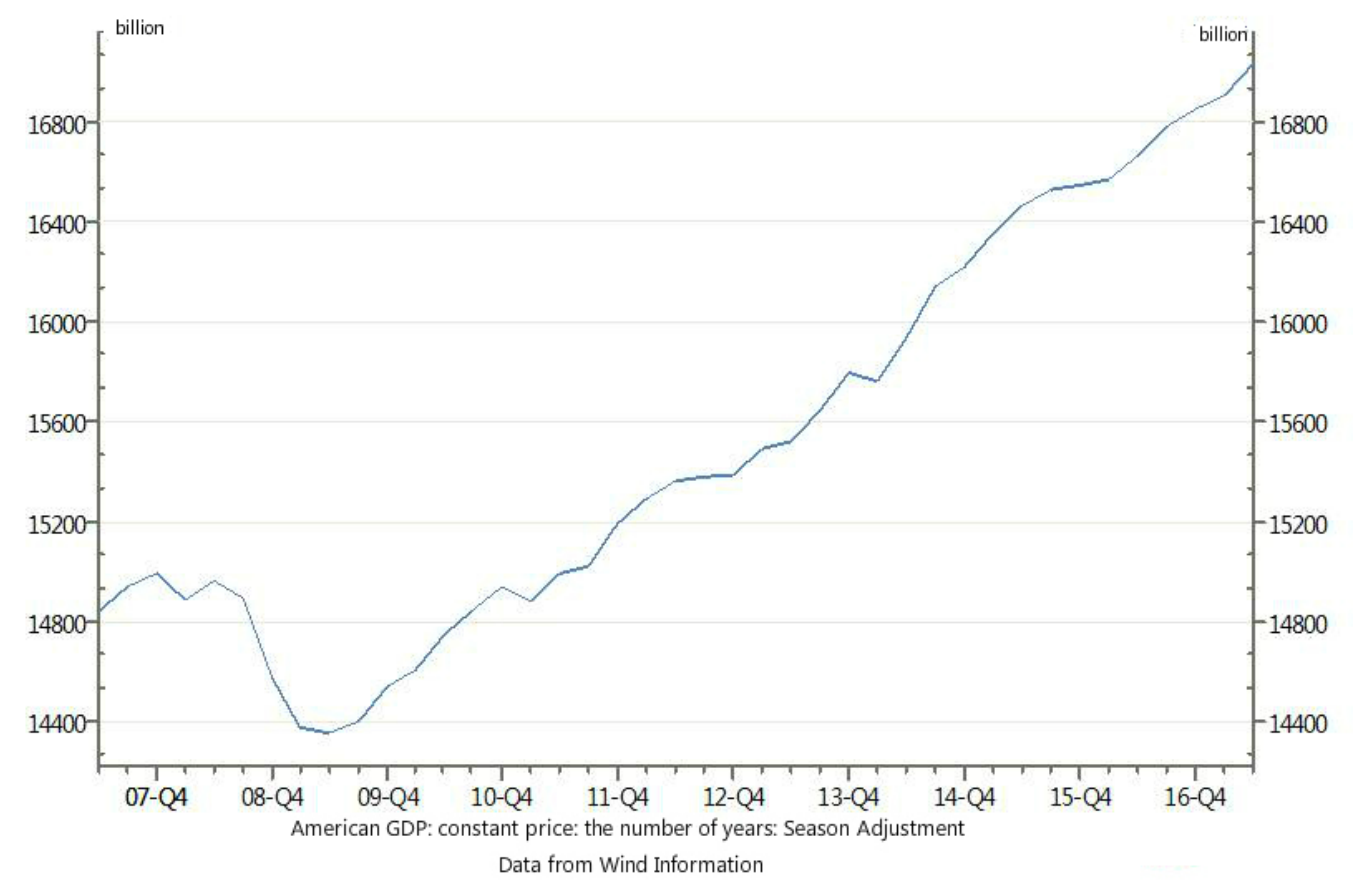

Fig.2. Trend of the GDP of America

Table 1. Increase rate of American GDP (\%)

\begin{tabular}{|c|c|c|c|c|c|c|c|c|c|}
\hline 2007 & 2008 & 2009 & 2010 & 2011 & 2012 & 2013 & 2014 & 2015 & 2016 \\
\hline 1.8 & -0.3 & -2.8 & 2.5 & 1.6 & 2.2 & 1.5 & 2.4 & 2.4 & 1.6 \\
\hline
\end{tabular}

Data source: Bureau of Economic Analysis of U.S. Department of Commerce

CPI. Inflation is an important factor in the exchange rate change. Fig. 3 shows the trend of American CPI in May 2007 to August 2017. On the one hand, according to the theory of purchasing power parity, domestic inflation reduces the purchasing power of money, the amount of value that represents the unit of currency decreased, unchanged in other circumstances, the need to pay more than the original currency for the same amount of foreign currency. On the other hand, changes in the rate of inflation have changed expectations of money demand, bond yields, and foreign currency values. In the case of constant exchange rate, inflation is unfavorable to exports and is favorable to import. Therefore, the demand for foreign currency increases and the demand for local currency decreases, resulting in the devaluation of the foreign currency. The consumer price index is usually used to measure inflation. 


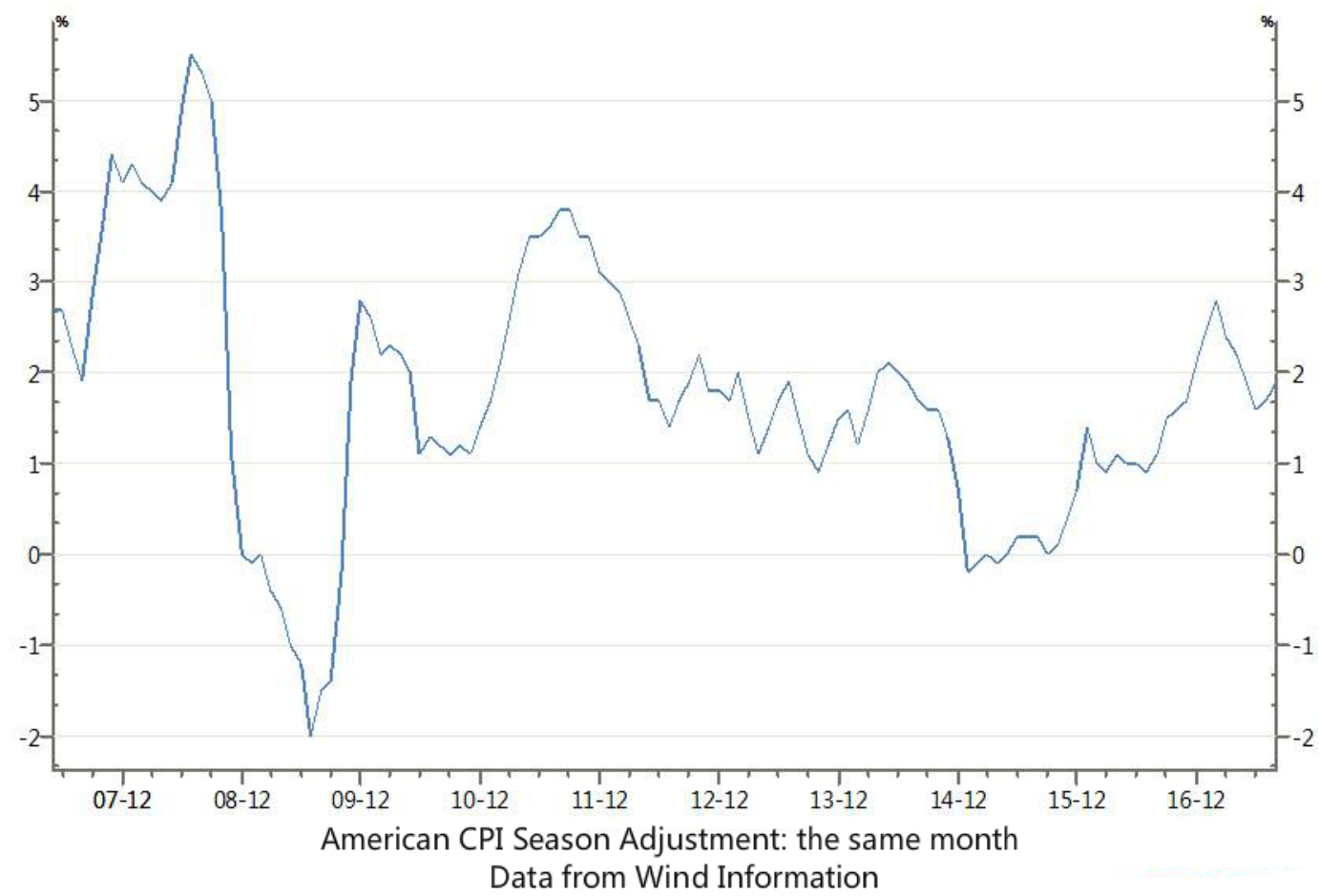

Fig. 3American CPI

Financial deficits. The difference between fiscal expenditure and fiscal revenue is called fiscal deficit. Fig. 4 shows the annual budget deficit of America from 2007 to 2016. In the period, the US fiscal deficit rose rapidly, and the deficit continued to decrease from 2009 to 2015, and increased slightly in 2016. The fiscal deficit will depress the dollar index in many ways. First of all, fiscal deficits are often accompanied by inflation. The fiscal deficit, government spending will increase dramatically, to increase the amount of money demand, and the goods in a short period of time and labor supply to increase, thus making the price rise, inflation, inflation will depress the dollar index. Secondly, when the deficit is in short supply, the demand for foreign goods and services is bound to increase, thus increasing the current account deficit and reducing the dollar index. Finally, in order to achieve fiscal revenue and expenditure balance, the government usually reduces the deficit by issuing additional currency and increasing taxes. The increase in the amount of money issued will lead to inflation, tax increases will reduce investors' earnings, curb foreign capital inflows, inflation and foreign capital inflows will reduce the dollar index. 


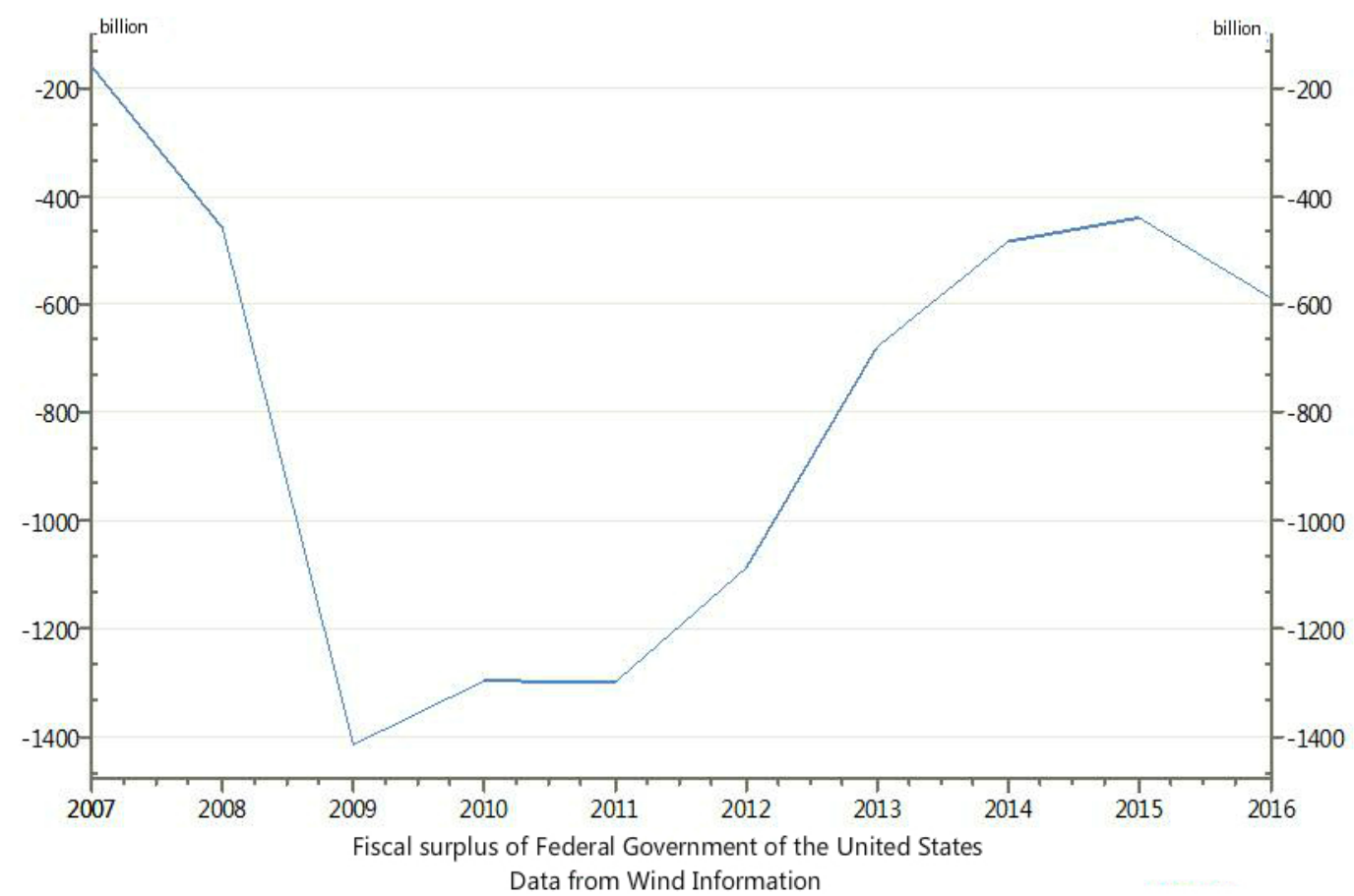

Fig. 4American annual budget deficit

Current account balance. According to the theory of the balance of payments theory, the current account surplus, the appreciation of the current account, the deficit of the current account and the devaluation of the currency. The US dollar index is stronger, the current account deficit increases, the current account deficit increases, and the dollar index decreases. As Fig. 5 shows, the proportion of current account deficit to GDP declined rapidly around 2008, and then decreased slightly, and fell to the lowest $-1.78 \%$ in the fourth quarter of 2013, with a slight rise in volatility. According to the exchange rate theory of the balance of payments, the dollar index response should take strong momentum in 2007 to the end of 2013 shows an overall decline, then the dollar index, with theoretical analysis and in the trend of the dollar index, the current account deficit is the reason for the dollar index volatility.

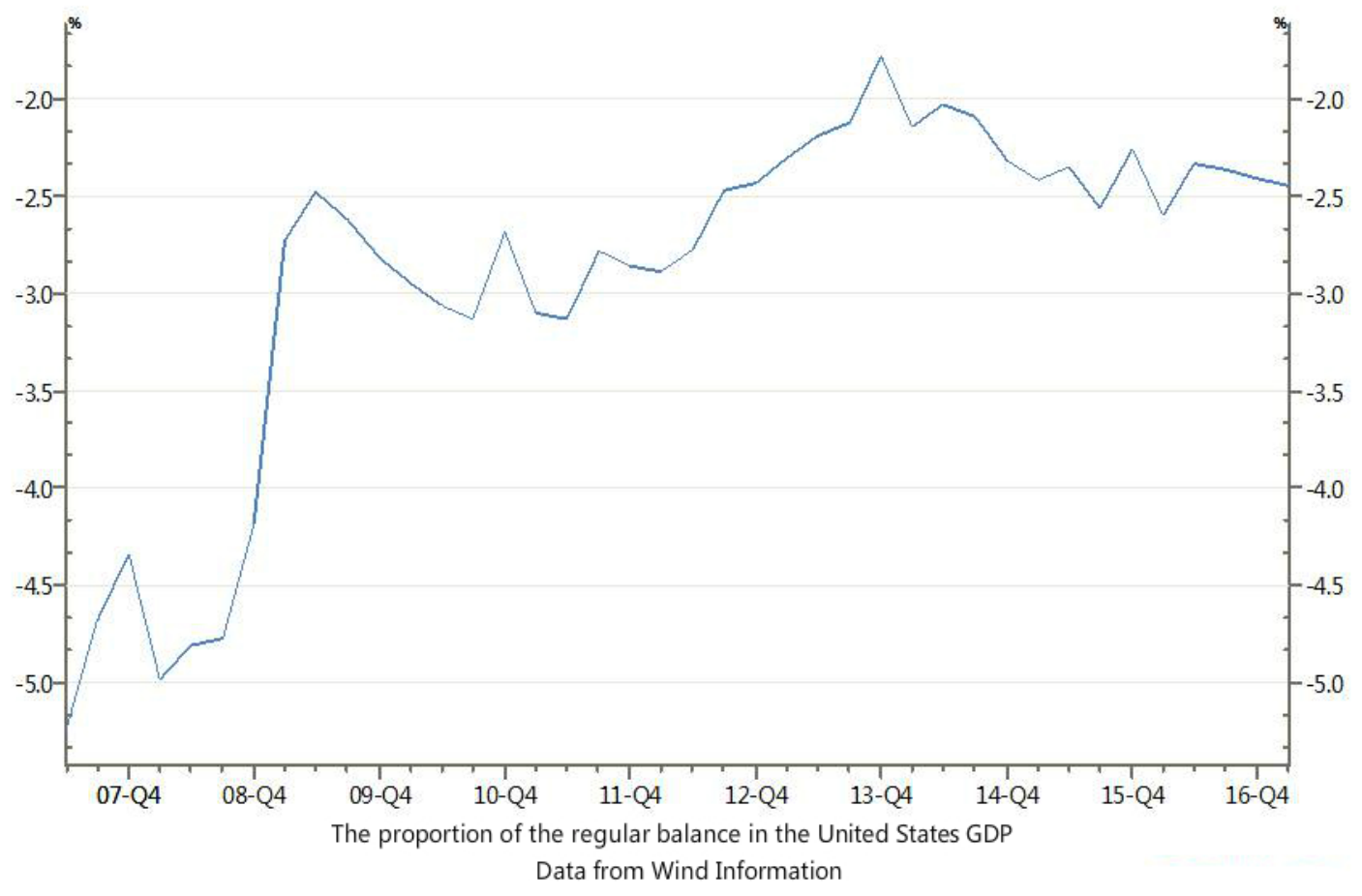

Fig. 5 Proportion of current account balance to GDP 
Gold price. Although the gold standard has already been replaced by the credit standard, gold and dollar linked double page with the collapse of the Bretton Woods system launched the stage of history, but gold has natural attribute of the precious metal, is still an important reserve currency country. Especially during the financial crisis, people regarded gold as an important means of hedging. Therefore, in the long run, the U.S. dollar and gold have a certain complementarity, the gold price will affect the U.S. dollar exchange rate.

\section{Conclusion}

The dollar is the most important currency of International Valuation and settlement, and the strength of the dollar directly affects the flow of international capital, thus affecting the global economy. It is of great significance to understand the factors affecting the exchange rate of the US dollar to understand and judge the global economic situation. The fluctuation and trend analysis of 2008 years after the global financial crisis, the dollar index, combining the exchange rate theory of international payments and the traditional exchange rate determination theory, the theory of purchasing power parity, factors that affect the dollar exchange rate changes, including: the gross national product (GDP), the rate of inflation (measured by the consumer price index CPI), finance balance of payments, the current account balance and the international price of gold. The economic growth is a key factor to influence the exchange rate. Economic growth in the United States not only directly affects the dollar exchange rate, but also indirectly affects the dollar exchange rate through a variety of channels.

\section{References}

[1] Chkili W, Nguyen D K. Exchange rate movements and stock market returns in a regime-switching environment: Evidence for BRICS countries[J]. Research in International Business and Finance, 2014, 31: 46-56.

[2] Simpson M W, Grossmann A. An examination of the forward prediction error of US dollar exchange rates and how they are related to bid-ask spreads, purchasing power parity disequilibria, and forward premium asymmetry[J]. The North American Journal of Economics and Finance, 2014, 28: 221-238.

[3] Li H, Ma H, Xu Y. How do exchange rate movements affect Chinese exports?-A firm-level investigation[J]. Journal of International Economics, 2015, 97(1): 148-161.

[4] Reboredo J C, Rivera-Castro M A, Zebende G F. Oil and US dollar exchange rate dependence: A detrended cross-correlation approach[J]. Energy Economics, 2014, 42: 132-139.

Beckmann J, Czudaj R. Oil prices and effective dollar exchange rates[J]. International Review of Economics \& Finance, 2013, 27: 621-636.

[5] McKinnon R, Schnabl G. China's exchange rate and financial repression: The conflicted emergence of the RMB as an international currency[J]. China \& World Economy, 2014, 22(3): 1-35.

[6] Lin Nan. International Monetary System in Multi-polar World DollarValuation Effect and RMB Exchange Rate Policy [J]. Chinese Review of Financial Studies, 2013(1): 91-104+126.

[7] Jian Zhihong, Zheng Xiaoxu. A Study on the Influence of RMB in Asia During the Process of Exchange Rate Reform: Based on the Perspective of Both Time and Space Dimension [J].World Economy Studies, 2016(3): 63-69+135. 